\title{
The Weston Papers: intellectual property law and the origins of the Centre for Commercial Law Studies at Queen Mary, University of London
}

\author{
Malcolm Langley \\ Queen Mary University of London
}

Despite the current prevalence of university courses in intellectual property law, the first UK academic Chair in the subject was created only thirty years ago. To commemorate this anniversary, this article draws upon primary sources from 1956 to 1980 to reveal the extensive role of the patent profession in a prolonged process that culminated in the establishment of the Herchel Smith Chair of Intellectual Property Law and the foundation of the Centre for Commercial Law Studies at Queen Mary, University of London.

Keywords: legal education, academia, university funding, philanthropy, patent agency, professional training, intellectual property law

During 2010, the Centre for Commercial Law Studies (CCLS) at Queen Mary, University of London celebrated its thirtieth anniversary. With several hundred postgraduate and doctoral candidates registered on its academic programmes plus many thousands of alumni around the world, CCLS has reached this milestone as one of the leading centres for teaching and research in commercial law. Anniversaries are generally a good time to look back, albeit usually with faded memory as the years pass, and the task of recall can often be greater with institutional memories as people move on and formal records become dispersed, disposed, lost and/or replaced by email. With this in mind, the Intellectual Property Archive at CCLS was fortunate to receive the private papers of W Weston relating to his role in establishing CCLS as a centre for academic study and professional training in industrial and intellectual property law. W Weston was a former President of the Chartered Institute of Patent Agents (CIPA) and member of the first CCLS Committee of Management, and these papers, ${ }^{1}$ which are several hundred in number, constitute a sizeable, unique and authoritative primary source detailing a prolonged process that culminated in the foundation of CCLS. To mark the anniversary of the Centre and the launch of the Queen Mary Journal of Intellectual Property, this article aims to give readers a respite from their regular reading by drawing extensively on the Weston Papers and other archive resources to provide an insight into the origins of CCLS, which has been documented only partially previously.

1. The papers were donated by WR Farwell, a colleague of W Weston at Phillips \& Leigh and former member of the CCLS Advisory Council. 
Following approval from the Governing Body of Queen Mary College for a new Centre for Commercial Law Studies, ${ }^{2}$ Lord Hailsham, ${ }^{3}$ then Lord Chancellor, formally opened the Centre on 20 June $1980 .{ }^{4}$ The stated purpose of CCLS was to advance 'the teaching and study of, research into and dissemination of knowledge pertaining to commercial law, its relationship to economic theory and its social and economic implications'. ${ }^{5}$ The Centre received a favourable preview in the Financial Times $^{6}$ and luminaries from the professions and academia attended the opening ${ }^{7}$ of which a report, including speech transcripts, is available in the CIPA Journal. ${ }^{8}$ CCLS was to operate through a cluster of law units, each covering a distinct area of commercial law. The first unit was Intellectual Property Law, which was intended to be quickly followed by Energy Law, Corporate Securities and, when funding became available, Credit and Security, Arbitration, Banking, International Trade and Insurance. ${ }^{9}$ The formation of intellectual property law as the first unit within CCLS provides an indication of the catalyst for the new centre. The initiative came from RM Goode, Crowther Professor of Credit and Commercial Law at Queen Mary College and subsequently CCLS Director (1980-89) and Honorary President (since 1989). Upon introducing a proposal to the Academic Board of Queen Mary College, he outlined the importance of commercial law and the absence of any English academic institution devoted to its systematic study, both of which created a need for a 'sustained and integrated examination of comparative commercial law'. ${ }^{10}$ Within this broader context, the minutes of the meeting record that RM Goode 'explained that the impetus for the establishment of the proposed Centre sprang from the endowment of the Chair in Industrial Property Law', 11 and, in correspondence, W Weston also confirmed this symbiotic relationship. ${ }^{12}$ The origins of CCLS, therefore, are not located within the usual internal academic administrative procedures but rather in a series of external attempts to establish the subject of industrial property law at a UK university, which culminated at Queen Mary College in 1980. The Weston Papers provide a rare opportunity to document the considerable roots of this process, which extend back to the 1950s.

The documentation relating to the earliest attempt to establish industrial property law in UK academia is sparse other than an apparently internal communiqué that references an initiative under the auspices of the Trade Marks, Patents and Designs Federation (TMPDF). This communiqué records that L Ellwood, TMPDF President, raised the prospect of a lectureship in the subject in 1956 and, although the idea

2. Queen Mary College, Governing Body, Minutes, 12 March 1980.

3. Queen Mary College, CCLS, Executive Committee, Minutes, 20 February 1980; JWF Nott, Secretary of State for Trade, was previously invited but he was unable to attend on any of four proposed opening dates.

4. Queen Mary College, CCLS, Committee of Management, Minutes, 14 July 1980.

5. Queen Mary College, CCLS, Constitution of the Centre for Commercial Law Studies [Para. 1].

6. AH Hermann, 'New Law School Deserves Support', Financial Times (London, 19 June 1980).

7. Queen Mary College, CCLS, Invitations to Official Opening.

8. FWB Kittel, 'University Foundation: Formal opening of the Centre for Commercial Law Studies', Queen Mary College, London E1 4NS (1980) 9 CIPA Journal 518.

9. RM Goode, Centre for Commercial Law Studies, 18 March 1980.

10. Ibid.

11. Queen Mary College, Academic Board, Minutes, 21 June 1979.

12. W Weston, Personal communication to H Smith, 13 March 1980. 
received support in the TMPDF Council, it was abandoned, intriguingly, because of the Suez Crisis. ${ }^{13}$ Two years later, in response to interest from LCB Gower, Sir Ernest Cassel Professor of Commercial Law at the London School of Economics and Political Science (LSE), the topic was again before the TMPDF Council. At this meeting, L Ellwood noted that there was no academic Chair or lectureship in the subject in the UK so, as part of a fact-finding exercise, he approached a number of companies to find out whether there was commercial interest in providing funds for an initiative in this direction. ${ }^{14}$ The list of companies contacted included Courtaulds, Esso, Monsanto, Dunlop, Shell, Unilever, Imperial Tobacco and British American Tobacco. At its next meeting, the findings revealed that only the latter three companies did not demonstrate any interest. ${ }^{15}$ However, the meeting raised concerns about the cost and type of instruction, with the attention of members drawn to the lecture series by TA Blanco White, Head of Chambers at 8 New Square, at the Sir John Cass Technical Institute in Aldgate. It is unclear though whether these lectures were viewed as a template for, or an alternative to, any potential TMPDF initiative. A subsequent TMPDF Council meeting in 1959 reported that HR Mathys, ${ }^{16}$ Deputy Chair of Courtaulds (and later to Chair the Committee to Examine British Trade Mark Law and Practice), ${ }^{17}$ and others met informally with LCB Gower at the Institute of Advanced Legal Studies. ${ }^{18}$ Following the meeting, LCB Gower formally expressed an interest in establishing a research fellowship in the law of industrial property through the Law Department at LSE, subject to obtaining external financial support of approximately $£ 4,000$ per year for seven years, at which point the post would be subject to review. ${ }^{19}$ Cautiously, he also noted that there would be problems in providing university facilities and that hardly any lawyers knew anything about this "particular branch of modern practice'. 20

The costing from LSE apparently returned the subject to a back-burner until extracts from TMPDF Council meeting minutes from 1964 reveal that the issue of academic study was again being discussed as the LSE and the Northampton Institute (now City University London) were both actively considering developing their interest in the subject. ${ }^{21}$ Representatives from the TMDPF approached GSA Wheatcroft, Professor of English Law at LSE, regarding the possibility of a fellowship co-funded by university and industry. At that time, the cost to industry was to be $£ 3,000$ over a three-year trial period. ${ }^{22}$ It appears that this initiative was mostly speculative and the last recorded correspondence on file from GSA Wheatcroft indicated that it might be

13. YM Ouzounian, Proposed University Lectureship in Industrial Property (1964) 1-5; enquiries as to her affiliation were unsuccessful but she is likely to have been an associate of L Ellwood in one of his many capacities.

14. TMPDF, Council Meeting, Minutes (Extracts), 12 December 1958.

15. TMPDF, Council Meeting, Minutes (Extracts), 9 January 1959.

16. JM Aubrey, 'Obituary: Sir Reginald Mathys' (1977) 6 CIPA Journal 528.

17. British Trade Mark Law and Practice: Report of the Committee to Examine British Trade Mark Law and Practice (Cm 5601, 1974).

18. TMPDF, Council Meeting, Minutes (Extracts), 13 February 1959.

19. Ouzounian (n 13) 3; for comparable present-day values of the financial figures quoted in this article, see Bank of England Inflation Calculator <http://www.bankofengland.co.uk/ education/inflation/calculator/index1.htm $>$ accessed 6 August 2010.

20. Ouzounian (n 13) 2-3.

21. TMPDF, Council Meeting, Minutes (Extracts), 10 April 1964.

22. TMPDF, Council Meeting, Minutes (Extracts), 8 May 1964. 
some time before a definite proposal would be forthcoming. ${ }^{23}$ Minutes from the TMDPF Council meeting in May 1964 confirmed that the idea was, to quote their golfing analogy, 'in the rough'. 24

The process regained momentum through JA Kemp, Senior Partner of JA Kemp \& Co., who was interested in creating a Chair in Industrial Property, preferably in London. JA Kemp wrote that HR Mathys had 'sparked' his interest in 1963 and he conducted an investigation as to why the efforts of the TMDPF had proven unsuccessful, concluding that any interest from industry was small unless it was a cheaper alternative to the in-house training of graduates. ${ }^{25}$ This conclusion has parallels with the findings of the Franks Report on Business Schools at that time, which highlighted a prevalence of mutual mistrust of intentions between academia and industry. Business, Lord Franks reported, was suspicious that academia was more 'concerned with the advancement of knowledge' than offering 'thoroughly vocational and practical' courses. On the other side of the coin, academics feared that business asked them to be 'magicians not educators', wanting short courses and quick results even though any education or training takes time to offer any real benefit or significance. ${ }^{26}$ In questioning the relationship between academia and industry, Lord Franks touched upon the debate over what universities are for, and what they should be doing, a debate that stretches back at least two centuries since W von Humboldt and JH Newman, and one that remains ongoing. ${ }^{27}$

During the summer of 1967, JA Kemp initiated discussions about creating a Chair in industrial property with G Brownlee, Professor of Pharmacology at King's College, who in turn secured the interest of RH Graveson, Dean of Laws and Vice-Chancellor. Shortly after this initial contact, JA Kemp received correspondence from HR Mathys lamenting the absence of someone who could provide an academic view to the Banks Committee (Committee to Examine the Patent System and Patent Law), ${ }^{28}$ which may have added further stimulus to the subsequent meeting. ${ }^{29}$ Talks over luncheon at King's College in November 1967 seemed to go well, with RH Graveson prepared to provide the necessary facilities to commence a Chair of Industrial Property by October 1968, if the right candidate and funds of $£ 4,500$ for five years were available by January. ${ }^{30}$ In correspondence, JA Kemp wrote that he was prepared to offer $£ 10,000$ of the required $£ 22,500$ from funds accumulating under the DMVK Trust ${ }^{31}$ and he seemed optimistic about raising the balance. ${ }^{32}$ This optimism softened over the winter though and, in February 1968, JA Kemp wrote to RH Graveson that raising the necessary finance might be difficult for a number of reasons including the 'chilly' climate in top industrial circles 'due, inter alia, to the enquiries on the patent system

23. Ouzounian (n 13) Supplement 1967.

24. TMPDF, Council Meeting, Minutes (Extracts), 8 May 1964.

25. JA Kemp, Chair of Industrial Property: Summary of Events, 19 January 1974.

26. OS Franks, British Business Schools: Report (British Institute of Management, London 1963) 6-7.

27. Boulton and C Lucas, What Are Universities For? (League of European Research Universities, Leuven 2008).

28. The British Patent System: Report of the Committee to Examine the Patent System and Patent Law (Cm 4407, 1970).

29. HR Mathys, Personal communication to JA Kemp, 4 September 1967.

30. JA Kemp, Personal communication to HR Mathys, 5 December 1967.

31. FWB Kittel, 'Benescience Foundation' (1981) 10 CIPA Journal 513.

32. $\operatorname{Kemp}($ n 30). 
being made by the Banks Committee' ${ }^{33}$ Despite this, by June 1970 , he was able to confirm the availability of funds without resort to industry, making $£ 15,000$ available from the DMVK Trust with a further $£ 10,000$ personal donation, subject to HM Inspector of Taxes approval as a tax-deductable revenue charge. ${ }^{34}$ Further cause for optimism was that GW Tompkin, a leading member of the Patent Bar and 8 New Square chambers, had indicated an interest in the post. ${ }^{35}$ Confidence was such that JA Kemp wrote to G Grant, TMPDF Secretary and former Comptroller-General of the Patent Office, enthusing 'we are at long last within sight of establishment of an effective Chair of Industrial Property'. ${ }^{36}$

With renewed hope, a meeting between JA Kemp and AR Mellows, then Director of Conveyancing Studies at King's College (now Lord Prior of the Order of St John), took place in July $1970 .{ }^{37}$ AR Mellows became involved after discussions with TE James, Vice-Principal of King's College (who had been approached by G Brownlee) as they were both keen that the Chair should become part of a new Centre for Property Law at King's College. ${ }^{38}$ A memorandum of this meeting was prepared by AR Mellows, in which he envisaged the potential appointee as Deputy Director of Property Studies initially and a permanent Chair to be established when further funds had been obtained, and for which the Deputy Director of Property Studies could then apply. Cautiously, he also raised the issue of an acute shortage of accommodation within the faculty. ${ }^{39}$

From this point, the process began to fall apart. GW Tompkin wrote that he had no interest in becoming a 'Deputy Director of Property Studies' as it would carry no weight abroad or give any indication of function. ${ }^{40}$ As the post required interaction between academic lawyers and scientists, he also believed that it needed to be based on-campus. ${ }^{41}$ In addition to these concerns, the timescale to establish a Centre for Property Studies was likely to push any appointment back to $1972-73 .{ }^{42}$ When a revised costing from King's College arrived in October, AR Mellows was 'somewhat embarrassed' to report that the cost had increased from the original $£ 22,500$ to $£ 26,820$ plus secretarial and travel expenses for a six-year post with the approximate status and salary equivalent to a Senior Lecturer (although outside the normal academic hierarchy). ${ }^{43}$ Just six days later, JA Kemp replied to AR Mellows that there was "no chance of securing the best man for the job unless he is given professorial status', ${ }^{44}$ and in further correspondence with WM Pybus, a lawyer and co-trustee of the DMVK Trust, he admitted that the King's College option was a 'dead duck' ${ }^{45}$ As he was departing from London on business, JA Kemp gave all the relevant papers to G Grant, TMPDF Secretary, as it was clear to him that the project to establish a

33. JA Kemp, Personal communication to RH Graveson, 5 February 1968.

34. JA Kemp, Personal communication to RH Graveson, 4 June 1970.

35. Ibid.

36. JA Kemp, Personal communication to G Grant, 4 June 1970.

37. AR Mellows, Memorandum: note of discussion between JA Kemp and AR Mellows, 13 July 1970 .

38. TE James, Personal communication to JA Kemp, 1 July 1970.

39. Mellows (n 37).

40. GW Tompkin, Personal communication to JA Kemp, 24 July 1970.

41. Ibid.

42. JA Kemp, Personal communication to GW Tompkin, 13 August 1970.

43. AR Mellows, Personal communication to JA Kemp, 6 October 1970.

44. JA Kemp, Personal communication to AR Mellows, 12 October 1970.

45. JA Kemp, Personal communication to WM Pybus, 12 October 1970. 
university Chair would need industry to support its costs. ${ }^{46}$ This effectively brought the second attempt to establish a Chair in Industrial Property to a close. However, it did not signal an end to JA Kemp's commitment to the project, and, in further correspondence, he pledged $£ 5,000$ from the Benescience Foundation (a successor to the DMVK Trust ${ }^{47}$ towards the cost of creating a Chair at a London university, ${ }^{48}$ and he would remain involved in the next attempt through CIPA.

Although the immediate prospect of a Chair had receded, the foundations for future progress continued as the subjects of professional training and industrial property were both gaining greater prominence. Just six months after the JA Kemp initiative ended, the Committee on Legal Education, chaired by Mr Justice Ormond, published its report in March 1971. The Lord Chancellor, Lord Gardiner, appointed this committee in December 1967 with terms of reference including 'to consider and make recommendations upon training for a legal vocational qualification' with particular reference to the 'contribution which can be made by the Universities and Colleges of Higher Education' ${ }^{49}$ At this time, it was possible to qualify for legal practice in England by passing examinations without any academic training. ${ }^{50}$ In a wide review, the report recommended that legal education should consist of three stages: the academic stage, the professional stage and continuing education or training. ${ }^{51}$ Within this framework, the report recommended that vocational courses should last no longer than 40 weeks (one academic year) and 'should be provided within the university and college of higher education structure' ${ }^{52}$ A majority of the committee also favoured merging the professional law schools - the College of Law and the Inns of Court School of Law - with appropriate universities. ${ }^{53}$ Although neither law school merged at the time (the College of Law now collaborates with the Open University and the Inns of Court School of Law merged with City University in 2001), the desirability of students receiving legal education within a university environment was gaining traction. The Central Council of Bar Students deemed an academic foundation as 'essential', ${ }^{54}$ although the availability of compulsory Local Education Authority grants for courses in the higher education sector (in comparison with the discretionary awards available at professional law schools) may have influenced their conclusion. ${ }^{55}$

Within this context of a general desirability for universities to provide legal education and training, the suitability of industrial property as an academic subject was also receiving support. A research report from Melbourne University Law School considered the academic merit of the industrial property courses at Sydney, Monash, Australian National University and the course module available on the then inter-collegiate

46. JA Kemp, Personal communication to GW Tompkin, 12 October 1970.

47. The Benescience Foundation later funded the John Kemp Scholarship to a prospective Patent Attorney on the MSc in Management of Intellectual Property at CCLS until 1998 when its funds were transferred to the Intellectual Property Educational Trust, which continues to fund this scholarship.

48. JA Kemp, Personal communication to G Grant, 6 August 1971.

49. Report of the Committee on Legal Education (Cm 4595, 1971) [1(2)(a)].

50. Legal Education: Central Council of Bar Students' evidence to the Lord Chancellor's

Legal Education Committee (Inns of Court School of Law, London 1969) 1.

51. Report of the Committee on Legal Education (n 49) [100].

52. Ibid [133-140].

53. Ibid [141-142].

54. Legal Education (n 50) 19.

55. Ibid, 5, 14-15 
University of London LLM. ${ }^{56}$ Its subsequent influence is evident in its citation by W Weston in another paper as providing confirmation that industrial property was of 'sufficient legal and practical interest and educative value to warrant teaching of it as a university law subject' ${ }^{57}$ A further development in favour of providing industrial property instruction through universities was the Strasbourg Conference on Training for the Patent Profession on 28-29 June 1973. This conference attracted around 150 people, ${ }^{58}$ including $\mathrm{W}$ Weston, and would have raised awareness among attendees that, in contrast with the situation in the UK, the Centre d'Etudes Internationales de la Propriété Industrielle (CEIPI) had provided training for students wishing to specialize in patent rights since $1964 .{ }^{59}$

The topic of professional training was also on the agenda within CIPA, where an internal paper presented by W Weston in March 1971 on revisions to the Qualifying Examination and the problem of training entrants to the patent profession seemed to 'strike a chord'. ${ }^{60}$ In view of the response to this paper, W Weston presented a proposal regarding the profession's examinations to the CIPA Council in August 1972, during his tenure as CIPA President. This paper recommended creating an Advisory Committee to examine the 'form and conduct' of examinations under the CIPA rules made in accordance with Section 89 of the Patents Act $1949 .{ }^{61}$ With approval of the proposal, the Council convened a Committee on the Training and Qualification of Patent Agents, chaired by PL Pratt, Professor of Crystal Physics at Imperial College. In its report, ${ }^{62}$ the committee reviewed the requirements for registration as a patent agent, identified an ideal skill set of a 'complete' patent agent, set out current examination procedures and reviewed existing training, which was primarily in-house company training supplemented by a series of tutorials organized by CIPA Fellows. The Informals, as these are known, started in 1953 with Monday evening lectures that usually attracted around fifty attendees. ${ }^{63}$ Among its recommendations for the future, the Pratt Committee Report stated that there should be a 'full-time formal course of instruction with a defined syllabus which includes the principles of patent law ... run at a suitable number of educational establishments' ${ }^{64}$ The report also recommended collaboration with universities to provide optional post-qualification courses in subjects not included in the Qualifying Examination, such as licensing and taxation, and the provision of further courses within the UK to study European patent law and procedure. ${ }^{65}$ The report envisaged establishing MSc courses in industrial property at universities, polytechnics or business schools or as a part-time course involving day-

56. DJ Ryan, Consideration of Industrial Property as a University Law Subject (Melbourne University Law School, Hawthorn 1973) received by W Weston in personal communication from N Waddleton, 3 December 1975.

57. W Weston, 'University Training in Industrial Property' (1976) 5 CIPA Journal 188.

58. 'The Strasbourg Colloque' (1973) 2 CIPA Journal 472.

59. Centre d'Etudes Internationales de la Propriété Industrielle (CEIPI, Paris 1973).

60. W Weston, 'A Qualifying Examination' (1971) 89 Transactions of the CIPA B58.

61. W Weston, 'Institute Examinations' (1972) 1 CIPA Journal 414.

62. Report of the Committee on the Training and Qualification of Patent Agents (CIPA, London 1973).

63. GH Edmunds, 'Discussion on University Training in Industrial Property' (1976) 5 CIPA Journal 96.

64. Report of the Committee on the Training and Qualification of Patent Agents (n 62) [Rec. $5]$.

65. Ibid [Rec. 19, Rec. 20]. 
release as the committee could see 'no practical way in which the cost of the courses could be covered other than by public funds' ${ }^{66}$

Beyond the terms of reference of the Pratt Committee, the pending process of European harmonization was another factor that drew the patent profession and universities closer together. Although there was no explicit provision for the harmonization of professional qualifications in the EC Treaty, ${ }^{67}$ there were a number of indirect requirements for a common market, such as freedom of movement of workers (Art. 48), cooperation in vocational training (Art. 118) and general principles for implementing a common vocational training policy (Art. 128). ${ }^{68}$ These provisions were all subject to the approximation of laws in member states (Art. 3). A CIPA Journal editorial regarded the harmonization of professional qualifications in the EEC, which would include the European Qualifying Examination for the forthcoming European Patent Office, as an issue that needed 'close examination', as harmonization could potentially diminish the influence of professional bodies in the examination process for entry into the professions. ${ }^{69}$ In a debate on professional training in the House of Lords, Lord Bowden, then Principal of the University of Manchester Institute of Science and Technology (UMIST), succinctly grasped the issue by noting the difference in culture between the UK 'where professional standing was assessed by a body of peers', and on the continent, where it is 'guaranteed by University degree' ${ }^{70}$ The sense of apprehension of the potential implications of European harmonization is evident in his earlier claim that the European Commission was framing regulations which, if implemented, could 'effectively take over the whole English educational system, and destroy the autonomy of our learned professions and chartered institutions'. ${ }^{71}$ Although easily dismissed now as a typically parochial view, anxiety over EEC membership was a recurring theme of the times and its influence is evident in the Weston Papers, where some correspondence highlights issues affecting CIPA such as freedom of establishment of self-employed workers and mutual recognition of professional qualifications. ${ }^{72}$

In addition to developments in professional training, the profile of industrial property was also increasing during this period. Sometimes regarded as 'an arcane professional craft of no genuine significance' previously, ${ }^{73}$ industrial property law started to emerge from its niche with a series of UK Parliamentary committees and international conventions. The aforementioned Banks and Mathys Committees reported in 1970 and 1974 respectively and, under the Chairmanship of Mr Justice Whitford, the Committee to Consider the Law on Copyright and Designs was constituted in February $1974 .^{74}$ Several international conventions were also signed during this

66. Ibid [Para. 69].

67. H Schur, 'The European Communities and the Harmonization of Educational and Professional Qualifications' (1975) 7 Journal of Librarianship and Information Science 49.

68. Treaty of Rome, 25 March 1957.

69. 'Editorial, Qualifications in the EEC' (1973) 2 CIPA Journal 382.

70. EEC Regulations and the Professions, Hansard HL vol 341 cols 524-615 at 531 (10 April 1973).

71. BV Bowden, 'Higher Education and the Professions: Problems of Harmonization' (1973) 23(1) European Review 28.

72. For example, JH Dunlop, Personal communication to W Weston, 18 July 1974 and 31 October 1974.

73. J Phillips and A Firth, Introduction to Intellectual Property Law, 4th edn (Butterworths, London 2001) 6.

74. Copyright and Designs Law: Report of the Committee to Consider the Law on Copyright and Designs (Cm 6732, 1977). 
period, including the Patent Cooperation Treaty ${ }^{75}$ and the Convention on the Grant of European Patents (European Patent Convention). ${ }^{76}$

During the intervening years, JA Kemp presumably retrieved the papers relating to his abortive approach to King's College from G. Grant and now forwarded them to E Armitage, Comptroller-General of the Patent Office. In reply, E Armitage wrote that he felt it was 'a pity' the UK did not have a national centre for study and training in industrial property and that 'Strasbourg and the Pratt Committee Report must now give considerable impetus to this matter' ${ }^{77} \mathrm{He}$ also expressed hope that CIPA would press for the establishment of a centre and he promised Patent Office support where possible but he suspected that the project would depend on whether support would be forthcoming from British industry. ${ }^{78}$

With the Patent Office deflecting responsibility to CIPA, its European Qualifications Committee (later the Qualifications Committee) took responsibility for implementing the relevant Pratt Committee Report recommendations. Chaired by W Weston, this committee included WE Caro, the Informals Committee nomination and later patron of the Bill Caro Prize in the Postgraduate Certificate in Intellectual Property Law at CCLS. At its first formal meeting in January 1974, the committee considered and discussed the Pratt Committee Report and the approaches already made to CIPA by City University, City of London Polytechnic, University of Bath, University of Southampton and Liverpool Polytechnic. ${ }^{79}$ The committee drafted a report for the next meeting of the CIPA Council and included three recommendations. ${ }^{80}$ The first was to take action to set up a course of instruction in industrial property 'at a university with facilities for instruction in law, science and languages and in London' ${ }^{81}$ Further recommendations: to formally approach the main Colleges of the University of London as well as City, Brunel, Southampton and Bath universities for consultation, to inform the Comptroller (E. Armitage) of the approach, and to obtain his assistance in gaining support from the Department of Education and Science, were also submitted and all three recommendations were approved. ${ }^{82}$

In reply to these approaches, CIPA received expressions of interest from City and Southampton; the approach was under consideration at Imperial College (which later transpired into interest $)^{83}$ and Brunel; there was no interest at that time from Bath, Queen Mary College, ${ }^{84}$ King's College or University College and no reply from LSE, ${ }^{85}$ which later transpired as no interest. ${ }^{86}$ Although King's College was not interested in 'technical courses for professions', which were not considered as part of its

75. Patent Cooperation Treaty (PCT) and Regulations under the PCT: done at Washington on 19 June 1970 (WIPO, Geneva 1970).

76. Convention on the Grant of European Patents (European Patent Convention) and attached annexes (Government of the Federal Republic of Germany, Munich 1973).

77. E Armitage, Personal communication to JA Kemp, 25 January 1974.

78. Ibid.

79. W Weston, European Qualifications Committee, Minutes, 30 January 1974.

80. W Weston, Report to Council by Qualifications Committee, September 1974.

81. W Weston, Report to Council by European Qualifications Committee, 5 March 1974.

82. 'Council News' (1974) 3 CIPA Journal 273.

83. BH Flowers, Personal communication to W Weston, 10 July 1974.

84. HW Melville, Personal communication to W Weston, 12 June 1974.

85. W Weston, European Qualifications Committee, Minutes, 11 June 1974.

86. C Grunfeld, Personal communication to W Weston, 26 July 1974. 
responsibilities, ${ }^{87}$ its reply did express an interest in reviving JA Kemp's initiative for a Chair of Industrial Property. ${ }^{88}$ Meetings between committee members and representatives of interested academic institutions followed. W Weston met with PL Pratt from Imperial College on 15 July 1974 from which an estimate of between $£ 25,000$ and $£ 30,000$ per year for three years was indicated as necessary to run a course, although Imperial had no 'availability at present for teaching of law'.89 The next day, RC Peterson met with D Jackson and G Dworkin (who became Herchel Smith Professor of Intellectual Property Law at CCLS, 1986-92) from the Faculty of Laws at the University of Southampton. RC Peterson reported that they had applied to the University Grants Committee (a predecessor to Higher Education Funding Council for England) for a grant to develop a new course in industrial property law, ${ }^{90}$ and that JC Lahore, a specialist in intellectual property law at Monash University, had confirmed he would be joining Southampton in $1975 .{ }^{91}$ A meeting with representatives from City University was delayed due to a change of Vice-Chancellor, ${ }^{92}$ whilst a further preliminary approach was made to the University of Warwick on the recommendation of a member of the CIPA Council, ${ }^{93}$ although there was no interest from Warwick in reply. ${ }^{94}$

Substantially, the outcome of these meetings was the conclusion that financing a new course was a problem and that virtually no money was available from ordinary university funds. ${ }^{95}$ An enquiry into how France financed its training elicited a response from $\mathrm{M}$ de Haas of CEIPI, who replied that French law required all industries to pay a levy of 0.8 per cent of their salary bill for training and that this percentage was due to rise to 2 per cent within three years. ${ }^{96}$ However, hesitant to approach government, $\mathrm{W}$ Weston believed that the profession should be self-reliant and that, even if some money were forthcoming from the taxpayer, the profession would be expected to contribute and 'surrender some measure of control'. 97 As such, he wrote to GA Bloxam, the CIPA President, requesting permission to ask CIPA Fellows whether they would be prepared to fund a university course in industrial property. ${ }^{98}$ There was a suggestion to name the proposed University Foundation appeal after Cecil Every, a distinguished member of the patent profession, being CIPA President (1948-49) and Editor of the CIPA Journal, who had died earlier that year. ${ }^{99}$ Although the CIPA Council initially gave its approval, ${ }^{100}$ it later revised this decision and decided to keep the University Foundation appeal and the Cecil Every Memorial separate. ${ }^{101}$

87. I Shaw, Personal communication to W Weston, 10 June 1974.

88. Ibid.

89. W Weston, Memorandum: Brief note of discussion between PL Pratt and W Weston, 15

July 1974.

90. RC Petersen, Report of a meeting with Southampton University, 16 July 1974.

91. D Jackson, Personal communication to RC Petersen, 18 July 1974.

92. W Weston, Qualifications Committee, Note to Committee, 12 November 1974.

93. JM Aubrey, Personal communication to W Weston, 16 September 1974.

94. WL Twining, Personal communication to PE Lincroft, 8 January 1975.

95. W Weston, Qualifications Committee, Minutes, 3 July 1974.

96. M de Haas, Personal communication to W Weston, 28 May 1974.

97. W Weston, Personal communication to RC Petersen, 14 August 1974.

98. W Weston, Personal communication to GA Bloxam, 26 September 1974.

99. W Weston, Personal communication to PL Pratt, 12 November 1974.

100. Weston (n 92).

101. W Weston, Personal communication to GA Bloxam, 24 February 1975. 
During this period, enquiries were undertaken into whether the University of London LLM course module in Industrial and Intellectual Property Law offered by W.R. Cornish, Professor of English Law at LSE, could provide a basis for candidates taking the CIPA Intermediate Exam. The conclusion of DJ Devons, of Marks \& Clerk, based on a copy of the 1974 course synopsis, was that the course in combination with a year's in-house training would be a sufficient basis to pass the exam. ${ }^{102}$ However, this did not meet the recommendations of the Pratt Committee Report, which sought a vocational course effectively to replace or provide exemption from the Intermediate Examination. ${ }^{103}$ The new course in industrial property law at the University of Southampton was also regarded as not being designed to meet the requirements of qualification for patent agency. ${ }^{104}$ As such, the committee subsequently drafted a University Foundation appeal letter, which GA Bloxam, CIPA President, circulated on 16 April 1975. The letter aimed to assess whether there was support within the profession, in principle, to provide $£ 100,000$ to establish a university course in industrial property rights by requesting individual subscriptions from Fellows ( $£ 25$ per Fellow per year for four years was indicated) and their firms. ${ }^{105}$ News of the CIPA fundraising appeal was reported in New Scientist, albeit not particularly favourably. ${ }^{106}$

On a significant day, CIPA also welcomed $M$ de Haas and $M$ Gilbert from CEIPI to give a presentation on its university courses on patents and licensing. ${ }^{107}$ The visit must have caused some awkwardness as the University Foundation appeal letter stated that CEIPI was being promoted as the sole training centre for patent agents for practice at the European Patent Office, whilst at the meeting the representatives from CEIPI said that their organization was not seeking any monopoly. ${ }^{108}$ In response, GA Bloxam requested 'comments' from W Weston, who had included the claim in the letter drafting process. ${ }^{109}$ The reply was probably unwritten, as it is not included among his papers, but in other correspondence, he cited E Armitage, the Comptroller, as the source of the assertion, ${ }^{110}$ and that there would be a de facto monopoly if no other university offered training in industrial property. ${ }^{111}$ It does seem as though the appeal letter overstated this claim and, in the context of the debate surrounding the pending June 1975 referendum on EEC membership, perhaps it was included to encourage subscriptions, although it did deter others. ${ }^{112}$ The report of the meeting also reveals a coincidence in that $\mathrm{R}$ Cullis, a Queen Mary College alumnus who has taught on the MSc in Management of Intellectual Property course at CCLS for the past two decades, signed the register as a CIPA Fellow that day. ${ }^{113}$

After one month, 20 per cent of CIPA Fellows had replied to the appeal letter, with a ratio of around 3:1 in favour and the appeal on course to reach the subscriptions

102. DJ Devons, Personal communication to W Weston, 4 March 1975.

103. Report of the Committee on the Training and Qualification of Patent Agents (n 62) 16-17.

104. W Weston, 'University Foundation' (1975) 4 CIPA Journal 262.

105. GA Bloxam, University Foundation, 16 April 1975.

106. 'Funds Sought for University Patent Course' (1975) 67 New Scientist 276.

107. '572nd Ordinary General Meeting' (1975) 4 CIPA Journal 272.

108. GA Bloxam, Personal communication to W Weston, 21 April 1975.

109. Ibid.

110. W Weston, Personal communication to JM Aubrey, 6 May 1975.

111. W Weston, Personal communication to HL Jukes, 6 May 1975.

112. D Vincent, Personal communication to NJ Flower, 8 August 1975.

113. '572nd Ordinary General Meeting' (n 107) . 
target of $£ 100,000$. Among those Fellows who declined to subscribe, the main issue was not cost but whether a university course was necessary for the profession and/or whether it was the responsibility of CIPA to fund any such course. ${ }^{114}$ By the time of the CIPA Council meeting in August 1975, sufficient support (40 per cent of Fellows in favour against 5 per cent opposed and no reply from 55 per cent) and subscriptions $(£ 62,212)^{115}$ had been received to decide to proceed with the project. W Weston convened a Preliminary Committee, which duly prepared and submitted a report on recommendations for a Chair, constitution, terms of reference and powers for a Substantive Committee. ${ }^{116}$ Following approval by the CIPA Council in January $1976,{ }^{117}$ a ballot from a list of nominations saw AW Beeston, JH Dunlop, B Fisher, GC Hargreaves, JA Kemp, W Weston and CG Wickham elected to serve on the committee. External invitations were extended to WM Pybus (Lawyer), E Armitage (Comptroller), G Brownlee (now Dean of the Faculty of Medicine, King's College), J. Spreadborough (CBI representative) and a member of the Council of the Royal Society of Arts (subsequently GLT Drummond). ${ }^{118}$ Appointment of a Chair was delayed pending finalization of the constitution of the committee.

After the demands of the Whitford Committee (of which W. Weston was a member) had eased, ${ }^{119}$ the newly constituted University Foundation Committee met for the first time in December 1976 and reviewed progress on the recommendations of the Pratt Committee Report. In view of the prevailing unfavourable economic conditions (the meeting was held in the midst of the Sterling crisis and the UK application for a $\$ 3.9$ billion loan from the International Monetary Fund), ${ }^{120}$ the objectives of the committee were reviewed. The committee gave priority to organizing a university course for studying the fundamental legal changes arising from the European Patent Convention, the Patent Cooperation Treaty and the new UK Patents Act (1977). From this course, the committee hoped that a regular university course might evolve. ${ }^{121}$ To test the feasibility of organizing a course, the committee agreed to approach the federal University of London rather than the individual colleges and invited PF Vowles (Academic Registrar) and B Groombridge (Director of ExtraMural Studies) to CIPA to discuss a potential patents course. ${ }^{122}$ At the meeting, there was positive interest in the proposal, with WR Cornish (LSE) and M Vitoria (then Lecturer in Law at Queen Mary College and a co-Lecturer on the University of London LLM course module in Industrial and Intellectual Property Law) ${ }^{123}$ mentioned as potential contributors. ${ }^{124}$ The committee subsequently arranged an

114. W Weston, Personal communication to PL Pratt, 16 May 1975.

115. W Weston, University Course Foundation: Report to Council, 31 July 1975.

116. CIPA, University Foundation Preliminary Committee, Minutes, 5 September 1975.

117. W Weston, Report to Members of the University Foundation Preliminary Committee, 9 January 1976.

118. W Weston, University Foundation Memorandum, 14 May 1976.

119. Copyright and Designs Law (n 74).

120. IMF Crisis, The Cabinet Papers, 1915-1979 <http://www.nationalarchives.gov.uk> accessed 6 August 2010.

121. W Weston, University Foundation Committee, Report of Meeting, 15 December 1976.

122. W Weston, University Foundation Committee, Report of Meeting, 23 February 1977.

123. WR Cornish, Intellectual Property: Patents, Copyright, Trade Marks and Allied Rights (Sweet \& Maxwell, London 1981) ix-xi.

124. W Weston, Report of the University Foundation Committee, CIPA Council Meeting, 22 March 1977. 
exploratory meeting with both academics at Russell Square. ${ }^{125}$ JD Ferguson represented E Armitage and reported that the committee viewed a course of perhaps ten days, extending over one day per week, on the new patent laws as 'a primer for a London University unit doing academic research in intellectual property and providing a qualifying course in place of the CIPA Intermediate Examination'. ${ }^{126}$ Following a further meeting, CIPA circulated a letter with a preliminary course announcement. Replies from Fellows favoured a short, intensive course and, consequently, the Department of Extra-Mural Studies arranged a course on new patent law at LSE from 3 to 7 April 1978, ${ }^{127}$ although it appears WR Cornish, M Vitoria and W Weston did the organizing, ${ }^{128}$ modestly described as 'some help' ${ }^{129}$ This course attracted maximum attendance of 60 to hear speakers including Mr Justice Whitford and RRH Jacob. ${ }^{130}$ In parallel to this CIPA course, M. Vitoria also organized a one-day conference on the Patents Act 1977 at Queen Mary College on 25 January 1978, with Sweet \& Maxwell subsequently publishing the collected papers. ${ }^{131}$

Developing short-courses in industrial property law was regarded as a primer for establishing the subject at a UK university and this ambition received a boost when the CIPA Council agreed in principle to mark its centenary in 1982 with the foundation of a University Chair or Readership in Industrial Property. ${ }^{132}$ The decisionmaking process behind this development is unclear as, unusually, it was not mentioned in the minutes of the CIPA Council at the time and W Weston communicated it in confidence to the University of London before the CIPA Centenary Celebrations Committee was convened. ${ }^{133}$ The CIPA Journal belatedly communicated this decision over a year later, in December 1978, when the process was nearing completion. ${ }^{134}$ This raises the possibility that the decision 'in principle' by the CIPA Council may not have been recorded as a formal commitment at that stage and there is an indication that W Weston was initially asked to explore the feasibility of such an option. ${ }^{135}$ Unfortunately, even the CIPA archives are unable to shed any further light on this development. ${ }^{136}$ Nevertheless, with the extra weight of this decision (whether confidential or informal) now behind the University Foundation Committee, invitations to its next meeting in February 1978 were extended to and accepted by FR Crane (Queen Mary College), WR Cornish (LSE), PL Pratt (Imperial College) and PF Vowles (Academic Registrar). At this meeting, GH Edmunds, CIPA Vice-President, took the vacant Chair of the committee at the request of W Weston. ${ }^{137}$ The meeting minutes reveal that discussions were noticeably more purposeful than previously, with a suggested timeline of an appointment by October 1981 and an

125. W Weston, University Foundation Committee, 9 June 1977.

126. JD Ferguson, IPCD.41289, Meeting, 11 July 1977.

127. W Weston, University Foundation Committee, Progress Report, 7 October 1977.

128. KDN Kearney, Personal communication to W Weston, 10 April 1978.

129. W Weston, Personal communication to GK Jennings, 15 March 1978.

130. W Weston, University Foundation Committee, Progress Report, 18 May 1978.

131. M Vitoria (ed), Patents Act 1977: Queen Mary College Patent Conference Papers (Sweet \& Maxwell, London 1978).

132. W Weston, Personal communication to PF Vowles, 7 November 1977.

133. 'Council News' (1977) 7 CIPA Journal 114.

134. 'Council News' (1978) 8 CIPA Journal 123.

135. Weston (n 132).

136. M Ralph (CIPA Secretary), Personal communication to author, 26 August 2010.

137. CIPA, University Foundation Committee, Minutes, 3 February 1978. 
endowment fund of $£ 400,000$ quoted as necessary for a professor, lecturer and secretary. ${ }^{138}$

It was shortly before this meeting that the prospect of a substantial donation had emerged, which probably explains the increased sense of purpose. The potential donor, Herchel Smith, was an organic chemist who devised new approaches to the synthesis of steroids. ${ }^{139} \mathrm{He}$ had amassed considerable wealth from over eight hundred worldwide patents derived from his work, ${ }^{140}$ the most commercially successful of which was for a synthetic progestational agent, the compound Norgestrel, which was widely used in oral contraceptives. ${ }^{141}$ Although his work had taken him to the USA, Herchel Smith was born in Plymouth after his father and three brothers (all bookmakers) moved there from the East End of London after serving in the First World War. ${ }^{142}$ Although Herchel Smith inherited the family flair for bookmaking, ${ }^{143}$ his career took a different path, reading natural sciences at Cambridge University $(\mathrm{PhD}, 1952)$ before heading to Oxford University for post-doctoral research and a lectureship in organic chemistry at the University of Manchester, where he began a working collaboration with Wyeth Laboratories before emigrating to join the American company in $1961 .^{144}$

After his retirement in 1973, he endowed a Chair in Tumour Immunology in the name of his late wife at the University of Cambridge to the value of $\$ 687,000$ and the announcement of this Chair attracted the attention of the University Foundation Committee. ${ }^{145}$ Correspondence within the Weston Papers reveals that GC Hargreaves, a committee member, proceeded to make initial contact with Herchel Smith in respect of the University Foundation appeal. ${ }^{146}$ GC Hargreaves was a former in-house patent agent at Wyeth Laboratories and had worked with Herchel Smith to file his first patent applications. ${ }^{147} \mathrm{He}$ later wrote that he had mentioned the University Foundation appeal when he visited Herchel Smith at his residence in West Chester, Philadelphia in January 1978 and that he had received a favourable response immediately. ${ }^{148}$ There was clearly a good rapport between the former colleagues, which extended to invitations to GC Hargreaves and his wife onto Herchel Smith's yacht Synthesis, ${ }^{149}$ twenty years after their working collaboration

138. Ibid.

139. H Smith et al., 'Totally Synthetic Steroid Hormones, Part I: Oestrone and Related Strapolyenes' (1963) Journal of the Chemical Society 5072; Totally Synthetic Steroid Hormones, Part II: 13 $\beta$-Alkylgona-1,3,5(10)-trienes, 13 $\beta$-alkygon-4-en-3-ones, and Related Compounds (1965) Journal of the Chemical Society 4472.

140. L Hall, G Hughes and JJ Lombard, 'Herchel Smith (1925-2001)', Oxford Dictionary of National Biography (Online edition) <http://www.oxforddnb.com/> accessed 10 September 2010.

141. GR Porter, Personal communication to W Weston, 1 February 1983.

142. E Smith, Letters: Herchel Smith, The Times (London, 15 March 2002).

143. Ibid; his father conceded his pitch at Newton Abbott racecourse to Herchel Smith and his cousin during their university vacations with Herchel Smith running the book, shouting the odds and always making a profit.

144. Hall, Hughes and Lombard (n 140).

145. 'Report of the General Board on the establishment of a Sheila Joan Smith Professorship of Tumour Immunology' (1977) Cambridge University Reporter 981 (27 July 1977).

146. W Weston, Personal communication to RC Petersen, 28 June 1979.

147. GC Hargreaves, 'Memories of Herchel Smith' (2002) 31 CIPA Journal 219.

148. Ibid.

149. Proceeds from the sale of his private yacht funded new chemistry laboratories at the University of Cambridge. 
ended. ${ }^{150}$ This probably made GC Hargreaves the best possible advocate for the University Foundation project, given that Herchel Smith had already decided to devote his retirement to philanthropy. ${ }^{151}$ Herchel Smith later wrote that he was 'very grateful for having this opportunity of aiding a profession to which I owe a great deal'. 152

Although the name of the potential benefactor remained confidential, in a draft of a proposed progress report to the CIPA Council, W Weston wrote:

Firm indication has been received through a Fellow of the Institute that a former client, who has become a very wealthy man through patents for his inventions, would be prepared to provide funds for endowment of a Chair in Industrial Property in the University of London provided that arrangements were such that the provisions of USA tax law concerning taxdeductable charitable gifts could be met. ${ }^{153}$

With the prospect of a single donation to finance a Chair, progress accelerated during 1978. A detailed course guide of the current Industrial and Intellectual Property Law course module of the inter-collegiate University of London LLM was supplied by WR Cornish, ${ }^{154}$ and he indicated that he was prepared to accept the Chair if it were endowed to LSE. ${ }^{155}$ Although there is reference to the letter only in passing, Lord Annan, the Vice-Chancellor of the University of London, initiated the next phase by writing to college Principals requesting expressions of interest in the CIPA proposal to endow a Chair in Industrial Property. ${ }^{156}$ Lord Annan directed replies to W Weston and meetings with college representatives took place during the autumn of 1978 .

The first meeting was with Queen Mary College over luncheon on 29 September 1978. GH Edmunds and W Weston met with KW Sykes (Vice-Principal), ${ }^{157}$ MV Saville (Deputy Registrar), RM Goode (Laws), AJ Boyle (Laws), PJ Clarricoats (Engineering), BA Corry (Economics), KR Simmonds (Laws), DA Smith (QMC Industrial Research Ltd) and M Vitoria (Laws). Following discussions, this working group prepared and submitted a six-page document in support of the application, ${ }^{158}$ which incorporated the various points raised and discussed in the meeting. The document initially stressed that its contents would not 'fetter the hands of the future appointee, if the Chair were to be established' (para.2). However, it agreed that industrial property was a suitable subject for academic study (para.3), that a lecturer, research fellow and a secretary would support the Chair initially (para.4) and that the college would establish degree and diploma courses in the subject. These courses would constitute a part-time postgraduate diploma, a pair of courses for the existing inter-collegiate LLM and industrial property law courses for science, engineering,

150. Hargreaves (n 147).

151. Ibid.

152. H Smith, Personal communication to W Weston, 27 May 1979.

153. W Weston, Personal communication to GC Hargreaves, 17 February 1978.

154. WR Cornish, Personal communication to W Weston, 15 May 1978.

155. WR Cornish, Personal communication to W Weston, 31 October 1978.

156. RGK Way, Personal communication to W Weston, 31 August 1978.

157. The Vice-Principal was representing JW Menter, the Principal, who had arranged the meeting but was unable to attend as he was in Fort William, Scotland after a mishap whilst on holiday.

158. Proposal by the Chartered Institute of Patent Agents for the Establishment of a Chair in Industrial Property Law: Response by Queen Mary College, University of London, undated, but enclosed with hand-delivered personal communication from JW Menter to W Weston, 27 October 1978. 
economics and laws undergraduates reading for a BSc or LLB (para.5). The document also envisaged 'advanced research, both national and comparative' as an integral part of the academic work to ensure that the UK would have an authoritative and influential presence in the field of industrial property law (para.13). The document also highlighted factors such as the strength of interest in commercial law and experience of multi-disciplinary collaboration to demonstrate the suitability of the college to receive the Chair (para.16). It concluded that the college would give 'full support to the teaching and research activities connected to the proposed Chair' if CIPA decided to establish this at Queen Mary College (para.17).

A second meeting took place at King's College on 2 October 1978 and was apparently much lower key. Although the initial expression of interest was from the Principal, Sir Richard Way, his reply suggested a meeting with AG Guest, Professor of English Law, and his secretary. In his hand-written meeting notes, W Weston wrote that King's College were prepared to accept a limited-life Chair, perhaps for five years, but there was a 'total capacity problem'. ${ }^{159}$ Two days later, W Weston and GH Edmunds met with $\mathrm{H}$ Billet (Professor of Mechanical Engineering and Acting Provost) and Lord Lloyd (Professor of Jurisprudence) at University College. The outcome of this meeting was an indication that University College was 'anxious' to institute a Chair in Industrial Property. ${ }^{160} \mathrm{H}$ Billet suggested a further meeting and that a strong case would be prepared in advance. The final meeting was on 11 October 1978 with C Grunfeld, M Wise and other interested but un-named law professors at LSE. As the meeting broke up in a 'slightly ragged and inconclusive manner', ${ }^{161}$ and as WR Cornish was on sabbatical in Australia, ${ }^{162} \mathrm{C}$ Grunfeld suggested that they met again in January to allow WR Cornish to lead the Law Department's representation. ${ }^{163}$ In view of the earlier involvement of PL Pratt in the process, that Imperial College did not express an interest this time was, presumably, because they did not have a law faculty.

Instead of arranging a second round of meetings, W. Weston prepared a further Progress Report and Proposed Recommendation to CIPA Council from the University Foundation Committee. ${ }^{164}$ This report gave conclusions drawn from the meetings with the four colleges. Problems were such that King's College was not a 'practical possibility', the LSE wanted to 'explore the general proposals in more detail' and University College had a genuine interest but 'it would be a considerable time before the interest could be set out in definite terms'. The unanimous view of the Working Party of the University Foundation Committee, therefore, was that 'Queen Mary College displays the strongest interest and the best-informed and practical approach among the four colleges'. ${ }^{165}$ Therefore:

It is recommended that Council should inform the University of London that the Institute is prepared to support the establishment of a Chair of Industrial Property law at Queen Mary College and, should the University be agreeable, invites discussion with University representatives with the object of financing and implementing foundation of a Chair in $1982 .{ }^{166}$

159. W Weston, Report of Meeting at King's College, 2 October 1976.

160. H Billet, Personal communication to W Weston, 19 October 1978.

161. ME Poole, Personal communication to W Weston, 12 October 1978.

162. Cornish (n 162).

163. C Grunfeld, Personal communication to W Weston, 1 November 1978.

164. W Weston, University Foundation Committee: Progress Report \& Proposed Recommendation, 28 November 1978.

165. Ibid.

166. Ibid. 
Following a lengthy debate, ${ }^{167}$ the CIPA Council approved this recommendation and relayed the decision to PF Vowles at the University of London on 6 December 1978 and to the colleges five days later. Considering the apparently formal committee culture within CIPA, it seems remarkable that the Working Group involved in the meetings, namely GH Edmunds, JD Fergusson, JH Dunlop, GC Hargreaves and W Weston, made the recommendation rather than the full University Foundation Committee. As with the apparent anomaly over the Centennial Appeal commitment to establish the Chair a year previously, it appears that the CIPA committee culture could give way to familiarity or expediency when required.

With a prospective home for a University of London Chair in Industrial Property decided, there was still considerable work needed regarding the potential source of funds, which may explain the swiftness in making the recommendation. To enable Herchel Smith to claim tax relief, he was required to channel his donation through a charitable organization, ${ }^{168}$ as US tax law does not allow donors to earmark funds (awards must remain at the discretion of charitable organizations with "no strings attached'). ${ }^{169}$ The British Schools and Universities Foundation (BSUF) emerged as a suitable candidate and Lord Annan made an initial approach on behalf of Queen Mary College. ${ }^{170}$ In reply, BFE Harvey, BSUF President, outlined that an application must be submitted through MM Cane, UK Honorary Secretary of BSUF, including a demonstrable record of cooperation between the applicant and the USA and contact details of an American representative for the project. ${ }^{171}$ In preparation of the application, W Weston visited all the parties concerned in person, including those in the USA, and he now seemed to be driving the process forward, with the rest of the committee informed of progress by telephone. Indeed, W Weston subsequently apologized to other committee members 'for having assumed a power to act' and asking for approval later. ${ }^{172}$

Queen Mary College submitted its application to BSUF in April 1979, meeting a timescale proposed by MM Cane. ${ }^{173}$ On a standard application form, the purpose of the request was 'to endow the foundation of a Chair of Industrial Property Law at Queen Mary College' that would strengthen Anglo-American educational ties 'by establishing in England the first University Chair, with research facilities, in Industrial Property Law for both United States and British students and practitioners' ${ }^{174}$ The amount initially typed in the application form was $£ 45,000$ instead of $£ 450,000$ but this was spotted and corrected prior to submission, averting a potentially costly error. ${ }^{175}$ To fulfil BSUF requirements, CM Dann, of Dann Dorfman Herrell and Skillman and former Commissioner of the US Patent Office, agreed to be the American representative whilst RM Goode provided details of links between Queen Mary College and the USA. Due to the ongoing industrial disputes during the "Winter

167. Council News (n 134).

168. W Weston, University Foundation Committee: Report of Action and Request for Whitewash, 11 April 1979.

169. BFE Harvey, Personal communication to H Smith, 23 May 1979.

170. NG Annan, Personal communication to BFE Harvey, 9 January 1979.

171. BFE Harvey, Personal communication to NG Annan, 26 January 1979.

172. Weston (n 168).

173. MM Crane, Personal communication to W Weston, 5 March 1979.

174. The British Schools and Universities Foundation: Application for Grant (Institutional) from Queen Mary College, University of London, England.

175. W Weston, Note to 'M.J.', undated. 
of Discontent' of $1978-79,{ }^{176}$ the application was telexed directly to MA Findlay, BSUF Secretary, in New York in addition to the formal postal route through MM Cane. ${ }^{177}$

A meeting of BSUF Directors on 18 April 1979 approved the application in principle, ${ }^{178}$ but approval was subject to confirmation that it was intended as a permanent endowment and not to 'dissipate the funds by giving bursaries', ${ }^{179}$ which RM Goode confirmed 'matched their intentions from the outset'. ${ }^{180}$ This assurance enabled MA Findlay to confirm approval of the application in correspondence with Sir James Menter, Principal of Queen Mary College, on 14 May 1979, ${ }^{181}$ and within a week, Herchel Smith had donated $\$ 850,000$ to BSUF. ${ }^{182}$ Although donors were not allowed to earmark funds, they were allowed to 'express an interest' in a particular project. In offering his donation, Herchel Smith wrote that he was 'interested in the Foundation supporting the endowment at Queen Mary College of the University of London of a Chair of Industrial Property Law as a permanent unit in the Faculty of Laws at that College'. ${ }^{183}$ Upon news of the donation reaching Queen Mary College, Sir James Menter contacted Herchel Smith to thank him personally and to request his approval to name the Chair as the Herchel Smith Chair of Industrial Property Law. ${ }^{184}$ All that remained was for the University of London to approve the establishment of the Chair in principle, which was confirmed in turn by the Academic Board of Queen Mary College ${ }^{185}$ the Governing Body of Queen Mary College, ${ }^{186}$ the Academic Council of the University of London, ${ }^{187}$ and finally, on 31 October 1979, by the Senate of the University of London. ${ }^{188}$

Following final approval, a recruitment advertisement for the new Chair appeared in 14 publications, including The Times and the Financial Times. ${ }^{189}$ One titular change between June and November was an amendment of the name to the Herchel Smith Chair of Intellectual Property Law, ${ }^{190}$ to incorporate copyright and related rights into the scope of the post. The advertisement attracted 'many applicants', ${ }^{191}$ and following receipt of a charitable award of $£ 392,000$ to Queen Mary College from BSUF, ${ }^{192}$ JC Lahore, Reader of Law at Monash University accepted the opportunity and took up his appointment on 1 January $1981 .{ }^{193}$ In fulfilment of the commitments

176. For a flavour of the dispute, see P Kerley, 'Winter of Discontent: 30 years on' <http://news.bbc.co.uk/1/hi/business/7598647.stm> accessed 6 September 2010.

177. Weston (n 168).

178. CIPA, University Foundation Committee, Minutes, 11 April 1979.

179. RM Goode, Personal communication to W Weston, 26 April 1979.

180. Ibid.

181. MA Findlay, Personal communication to JW Menter, 14 May 1979.

182. H Smith, Personal communication to BFE Harvey, 15 May 1979.

183. Ibid.

184. JW Menter, Personal communication to H Smith, 15 June 1979.

185. Queen Mary College, Academic Board, Minutes, 21 June 1979.

186. Queen Mary College, Governing Body, Minutes, 27 June 1979.

187. Queen Mary College, Governing Body, Standing Committee, Minutes, 10 October 1979.

188. Queen Mary College, Governing Body, Minutes, 14 November 1979.

189. For an example, see Bulletin Board, The Chronicle of Higher Education (Washington, DC, 7 January 1980).

190. Queen Mary College, Academic Board, Minutes, 1 November 1979.

191. GH Edmunds, Personal communication to RM Goode, 18 February 1980.

192. Queen Mary College, CCLS, Committee of Management, Minutes, 18 March 1980.

193. Queen Mary College, Governing Body, Minutes, 25 June 1980. 
given to CIPA and BSUF, further arrivals soon followed this appointment: Y.M. Smyth as Lecturer in Intellectual Property (from City of London Polytechnic) and V. Cottington as Secretary to the Intellectual Property Law Unit. ${ }^{194}$ Plans were also under way to create research facilities with a library to house a specialist intellectual property collection and a small number of reader spaces, ${ }^{195}$ with an ambition to acquire 'every text in English on intellectual property law'. ${ }^{196}$ The fledgling Intellectual Property Law Unit would later receive further financial support from the patent profession as beneficiary of the CIPA Centennial Appeal in 1982. ${ }^{197}$

The establishment of the Herchel Smith Chair of Intellectual Property, together with its related staff and research facilities, gave CCLS its first operational law unit, ${ }^{198}$ and the Centre subsequently evolved into its present-day appearance at 67-69 Lincoln's Inn Fields. The story of that journey is for another day, perhaps, but the Weston Papers reveal the significant personal endeavours of W Weston, ${ }^{199}$ JA Kemp, 200 GC Hargreaves and their colleagues at CIPA that culminated in the establishment of the Herchel Smith Chair of Intellectual Property, which in turn provided the impetus for RM Goode to establish CCLS in 1980. Of course, this undertaking would not have been as successful without the generous philanthropy of Herchel Smith, ${ }^{201}$ who, in addition to funding the endowment of a Chair, later provided further endowments for a research fellowship, ${ }^{202}$ a lectureship and scholarships, ${ }^{203}$ and, upon his death, a multi-million dollar bequest, ${ }^{204}$ which remains the largest donation made to the College. ${ }^{205}$ In accepting the bequest, which provided further financial support for the three existing endowments, the Principal and Financial Secretary provided 'secure firm assurances' that the endowments would be held 'in perpetuity' and be appropriately managed to ensure their 'long-term undiminished viability', ${ }^{206}$ thereby assuring the future of training, teaching and research in intellectual property law at Queen Mary, University of London. In tracing the origins of the Centre for Commercial Law Studies for a new generation of readers, this article recalls, recognizes and pays tribute to this considerable legacy.

194. Queen Mary College, CCLS, Director's Report 1980/81, November 1981.

195. RM Goode, Personal communication to GH Edmunds, 28 August 1980.

196. Queen Mary College, CCLS, Committee of Management, Minutes, 28 January 1980.

197. JU Neukom, 'Centenary Appeal' (1983) 12 CIPA Journal 271.

198. JC Lahore, 'The New Venture at QMC' (1981) 10 CIPA Journal 433.

199. SD Votier, 'Obituary: Walter Weston OBE, 1913-1987' (1987) 16 CIPA Journal 229.

200. DL Cannon, 'Obituary: John Arthur Kemp, 1913-2000' (2001) 30 CIPA Journal 171.

201. Obituary: Herchel Smith, The Times (London, 8 February 2002).

202. Queen Mary College, CCLS, Committee of Management, Minutes, 14 June 1982.

203. W Weston, Personal communication to H Smith, with Progress Report and Proposal to BSUF, 14 November 1984.

204. JJ Lombard (McCarter \& English LLP), Personal communication to K Aldred (Secretary \& Registrar, Queen Mary \& Westfield College), Re: Estate of Dr Herchel Smith, 28 December 2001.

205. £6.5 million gift to Queen Mary (2002) 6 (July) Bulletin: Newsletter for Staff and Students 1.

206. Will of Dr Herchel Smith, Section Eighth, 32-35. 